\title{
KOMPUTERISASI SEBAGAI MEDIA KARYA TIPOGRAFI EKSPERIMENTAL
}

\author{
Dria Setiautami \\ Jurusan Desain Komunikasi Visual, Fakultas Komunikasi dan Multimedia, \\ Bina Nusantara University, Jln. K.H. Syahdan No. 9, Palmerah, Jakarta 11480 \\ driasetiautami@binus.edu
}

\begin{abstract}
Typography is one of the elements design, which one designer can make their own style with it. As we know, the computer era move so fast, so we have to know how we get the basic visual from the personal computer. The fact is the shape of typography can'tbe changes, that's why we have to know how to change them and get another expression for the form. With the personal computer we can do the exerimentala of typography with the rules and breaking the rules.
\end{abstract}

Keywords: typography, experimental, computerised

\begin{abstract}
ABSTRAK
Tipografi merupakan salah satu elemen desain dalam komunikasi visual.dimana desainer dapat memilih bagaimana gaya visual yang dikehendaki. Sesuai perkembangan jaman tehnologi yang sangat cepat , sehingga sebaiknya kita harus mengenal cara - cara dasar untuk mencapai visual yang kita inginkan. Pada dasarnya bentuk huruf tidak lah berubah, tapi bagaimana kita membuat atau mengekspresikan suasana dan rasa tertentu atau beksperimen dengan kemudahan teknologi yang kita dapat. Dengan adanya komputer pribadi (personal computer) menjadikan ajang eksperimental tipografi, seperti yang akan dibahas dalam artikel ini. Sehingga menciptakan eksperimen yang di luar batas batas formalitas dalam kaidah tipografi sebelumnya
\end{abstract}

Kata kunci: tipografi, eksperimental, komputerisasi 


\section{PENDAHULUAN}

Tipografi merupakan salah satu elemen desain dalam komunikasi visual.dimana desainer dapat memilih bagaimana gaya visual yang dikehendaki. Sesuai perkembangan jaman tehnologi yang sangat cepat, sehingga sebaiknya kita harus mengenal cara-cara dasar untuk mencapai visual yang kita inginkan. Pada dasarnya bentuk huruf tidak lah berubah, tapi bagaimana kita membuat atau mengekspresikan suasana dan rasa tertentu atau beksperimen dengankemudahan teknologi yang kita dapat. Tipografi sangat dipengaruhi oleh keberadaan teknologi, karena itu makin dibuat supaya semakin mudah dan jelas "keterbacaan"nya (legibilitasnya) ini disebabkan dengan adanya banyak literasi yang telah membahas tipografi, sehingga dari yang kurang jelas atau tidak mudah keterbacaannya dibuat sedemikian rupa sehingga jelas dan mudah dibaca dengan menggunakan teknik-tehnik dalam tehnologi baru. Dengan adanya komputer pribadi (personal computer) menjadikan ajang eksperimental tipografi, seperti yang akan dibahas dalam diktat ajar ini. Sehingga menciptakan eksperimen yang di luar batas batas formalitas dalam kaidah tipografi sebelumnya.

Sebetulnya Tipografi Eksperimental ini bukan sesuatu yang baru, sesuai dengan perkembangan jaman dalam gaya desain grafis dalam abad 20 ini misalnya Futurism, de Stijl, Dada, Constructivism, and Post Modern memberikan respon pada teknologi dan membuat perkembangan yang luar biasa pada bidang tipografi. Dalam jurnal ini dibahas tentang kesempatan pengembangan eksperimental dalam tipografi dengan menggunakan potensi - potensi dalam teknologi. Dimana bisa membantu dalam proyek nyata untuk membuat visual yang mempunyai karakter di luar kaidah formal.

Sebelum memasuki dunia Tipografi Eksperimental kita harus mengenal kaidah kaidah (pedoman dasar) penggunaan tipografi yang dasar dalam desain komunikasi visual sehingga tercapai komunikasi yang efektif.Karena dengan memahami pedoman dasar tipografi dengan baik, kita dapat bereksperimen tanpa lepas dari basis pada prinsip prinsip dasar tersebut, sehingga tidak lepas dari fungsi dan tujuan visual tersebut tapi dengan gaya visual yang "out of box" atau keluar dari pakempakem standar. Karena pada dasarnya tipografi bisa menjadi salah satu yang terpenting dalam desain kmunikasi visual yang dapat memberikan efektifitas yang maksimal sehingga jika terjadi kesalahan atau ketidak pahaman pada tipografi dapat mengakibatkan rusaknya visual grafis dan tujuan komunikasinya .Jurnal ini untuk memahami prinsip prinsip dasar tipografi dan bagaimana cara mengembangkan sehingga menghasilkan desain desain yang eksperimental dalam tipografi tanpa mengurangi atau merubah komunikasi visualnya.

\section{PEMBAHASAN}

\section{Prinsip Dasar Tipografi}

Adalah aturan main yangmerupakan prinsip -prinsip pembuatan karya tipografi yang baik dan benar.Dimana jika kita mengikuti aturan aturan tersebut diatas secara langsung kita mendapatkan hasil yang mudah dicerna karena komunikasi yang jelas, teratur, terarah sesuai prinsip desain pada umumnya.

\section{Mematuhi Aturan Main dalam Tipografi}

Dalam waktu yang telah lama prinsip dasar tipografi selalu berkembang untuk memaksimalkan fungsi baik dari segi keindahan bentuk huruf tersebut ataupun kemudahan terbacanya dalam menuangkan komunikasi secara tertulis. Prinsip prinsip dasar tipografi ini bukan mutlak harus di turuti dalam mendesain, tapi prinsip dasar ini telah teruji dan terbukti kebenarannya. Dengan 
menggunakan prinsip dasar ini maka desainer dapat menuangkan ide sesuai isi (konteks) dan penyesuaian terhadap bentuk huruf itu sendiri secara maksimal.

Sebelum kita melakukan eksperimen, maka kita harus mengaetahui prinsip yang sangat dasar, sehingga setelah kita berksperimen akan tampak nyata pebedaannya mana yang telah di desain dengan baik tapi biasa, atau di desain dengan baik tapi luar biasa. Dari sini kita dapat menilai desain yang biasa akan lebih mudah dilupakan karna tidak mempunyai keunikan. Tetapi desain yang luar biasa menggunakan prinsip dasar yang telah diksplorasikan sehingga mempunya nilai lebih unik tapi dapat memberikan atau menyampaikan komunikasi yang sama dan tidak mengubah arti.Dengan perkembangan tipografi yang makin maju.prinsip dasar ini memberikan fakta penyelesaian yang teruji bagi khalayak umum.

\section{Aturan Main dalam Tipografi}

\section{Aturan 1}

Untuk mencapai keterbacaan yang mudah dan jelas gunakannlah jenis huruf yang sudah teruji dan terbukti sejak dahulu. Para desainer akan mempunyai karakter tersendiri pada dasarnya, sehingga mereka pun memiliki jenis huruf yang paling mereka sukai. Biasa betuk yang disukai berupa karakter yang sederhana dan mudah keterbacaan yang bisa dilihat dari bentuk konsisten dan perpaduan proporsi yang tinggi.Jenis huruf tersebut dibawah yang sudah terui keterbacaannya.

Contoh:

Jenis huruf SERIF = Baskerville $\mid$ Bembo $\mid$ Bodoni $\mid$ Caslon $\mid$ Garamond $\mid$ Goudy Old style | Sabon | Times New Roman | Pepertua | Palatino

Jenis huruf SAN SERIF = Franklin Gothic $\mid$ Frutiger $\mid$ Gill Sans $\mid$ Helvetica $\mid$ Futura $\mid$ Univers $\mid$ News Gothic | Myriad |

\section{Aturan 2}

Sebaiknya tidak banyak menggunakan jenis huruf yang berbeda dalam sebuah desain.Biasanya menggunakan jenis huruf yang banyak dengan tujuan memberikan penekanan (emphasis) atau untuk membedakan antara bagian satu dengan lainnya. Jika terlalu banyak jenis huruf mengakibatkan visual menjadi kacau balau sehingga pembaca tidak lagi dapat membedakan mana yang penting (utama) atau mana yang tidak penting.

Contoh:

$$
\begin{aligned}
& \text { permainan dalam eksperimental } \\
& \text { TIPOGRAFI adalah untuk } \\
& \text { memperluas batasan dengan cara } \\
& \text { membebaskan bentuk dari visual } \\
& \text { yang mempunyai arti kata } \\
& \text { sebenarnya dan juga hubungan } \\
& \text { antara kata dengan gambar. }
\end{aligned}
$$

\section{Aturan 3}

Hindari penggunaan kombinasi jenis huruf yang tidak terlalu kelihatan perbedaan bentuk fisiknya.Alasan utama menggunakan perbedaan huruf adalah memberi penekanan. Jadi sangatlah penting untuk menghindari yang tidak jelas perbedaan bentuknya sehingga jika kita melihat bukanlah seperi penekanan tetapi melainkan seperti membuat kesalahan visual, karena tidak kontras perbedaan bentuknya. 
Contoh:

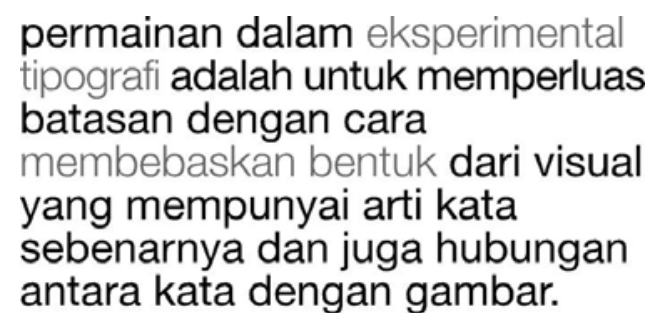

\section{Aturan 4}

Jangan menggunakan huruf kapital (huruf besar) semua pada teks yang panjang, tapi gunakanlah huruf besar dan kecil untuk keterbacaan yang maksimum.Huruf kecil akan lebih mudah keterbacaannya karna mempunyai "pengantar visual” (memudahkan mata untuk mengikuti alur visual) yang terjadi di dalam garis asender dan desender.Huruf besar akan lebih optimal jika digunakan sebagai teks yang berupa judul (bukan berupa kalimat yang panjang)

Contoh:

JANGAN MENGGUNAKAN HURUF KAPITAL (HURUF BESAR ) SEMUA PADA TEKS YANG PANJANG, TAPI GUNAKANLAH HURUF BESAR DAN KECIL UNTUK KETERBACAAN YANG MAKSIMUM. HURUF KECIL AKAN LEBIH MUDAH KETERBACAANNYA KARNA MEMPUNYAI "PENGANTAR VISUAL" (MEMUDAHKAN MATA UNTUK MENGIKUTI ALUR VISUAL) YANG TERJADI DI DALAM GARIS ASENDER DAN DESENDER. JANGAN MENGGUNAKAN HURUF KAPITAL

Tapi gunakanlah huruf besar dan kecil untuk keterbacaan yang maksimum. Huruf kecil akan lebih mudah keterbacaannya karna mempunyai "pengantar visual” (memudahkan mata untuk mengikuti alur visual) yang terjadi di dalam garis asender dan desender.

\section{Aturan 5}

Gunakan ukuran huruf yang telah terbukti keterbacaannya sesuai kebutuhan dalam konteksnya.Teks yang dibaca untuk jarak sekitar $30-40 \mathrm{~cm}$, biasanya ukuran huruf berkisar $8-12$ poin, tapi ada juga beberapa jenis huruf yang jika dipakai dengan ukuran tersebut tampak lebih besar atau lebih kecil dari ukuran standar huruf lainnya. Ini tergantung dari "x-height" atau tinggi huruf (jarak tinggi antara baseline dan meanline).

Contoh:

Gunakan ukuran huruf yang telah terbukti keterbacaannya

Gunakan ukuran huruf yang telah terbukti keterbacaannya

$=8 \mathrm{pt}$

Gunakan ukuran huruf yang telah terbukti keterbacaannya

$=10 \mathrm{pt}$

Gunakan ukuran huruf yang telah terbukti keterbacaannya

$=12 \mathrm{pt}$

$=14 \mathrm{pt}$

\section{Aturan 6}

Hindari penggunaan ukuran huruf (point-size) yang terlalu banyak pada saat yang bersamaan. Untuk menggunakan berbagai macam ukuran huruf biasanya dipakai sebagai penekanan hirarki membaca, sehingga jika berlebihan akan mengacaukan.Josef Muller-Brockmann menyarankan untuk tidak lebih dari 2 ukuran huruf pada satu judul “display text” (bisa dikategorikan poster misalnya), dan untuk menarik perhatian dan menambah maksimal fungsi sebaiknya diukur sesuai kebutuhannya.

Contoh:

Untuk menggunakan berbagai macam ukuran huruf biasanya dipakai sebagai penekanan hirarki untuk membaca, sehingga jika berlebihan akan mengacaukan. 


\section{Aturan 7}

Gunakan jenis huruf yang ketebalannya normal. Hindari yang terlalu tebal atau terlalu tipis untuk memudahkan ketrbacaan. Ketebalan dari suatu jenis huruf tergantung lebar dari stroke huruf tersebut. Stroke yang terlalu tipis membuat mata kita susah membedakan dengan latar belakang begitu juga sebaliknya stroke yang terlalu tebal membuat detail huruf menjadi berkurang sehingga sulit keterbacaannya. Jenis huruf yang book sangat ideal stroke-nya sehingga muda keterbacaannya.

Contoh:

Gunakan jenis huruf yang ketebalannya normal.Hindari yang te rlalu te bal atau terlalu tipis untuk memudahkan keterbacaannya

\section{Aturan 8}

Gunakan proporsi huruf yang medium, hindari jenis huruf yang proporsi terlalu lebar atau luas (expands) atau sebaliknya, yang terlalu kecil atau sempit (condensed). Distorsi pada ukuran huruf akan membuat huruf tersebut menyempit atau melebar sehingga membuat orang lebih sulit membacanya, walaupun memang sudah ada beberapa jenis huruf yang berbentuk expand atau condensed yang didesain sehingga mudah keterbacaannya.

Contoh:

Gunakan proporsi huruf yang medium, hindari jenis huruf yang proporsi terlalu lebar/ luas (“expands”) atau sebaliknya, yang terlalu kecil atau sempit (“condensed”) Gunakan proporsi huruf yang medium, hindari jenis huruf yang proporsi terlalu lebar/ luas ("expands") atau sebaliknya, yang terlalu kecil atau sempit (“condensed”)

\section{Aturan 9}

Untuk teks yang panjang gunakan jarak antar huruf (kerning) dan jarak antar kata juga spasi yang konsisten, tidak berubah ubah jarak (ruang kosongnya) sehingga mudah keterbacaannya. Huruf harus mempunyai jarak yang konsisten dan alami sehingga terbaca menjadi sebuah kata, begitu juga kata harus demikian sehingga terbaca menjadi sebuah kalimat, dan seterusnya menjadi sebuah paragraf. Sehingga disini terlihat betapa peran pentingnya ruang kosong yang proporsional pada penyusunan huruf yang akan dibaca.

Contoh:

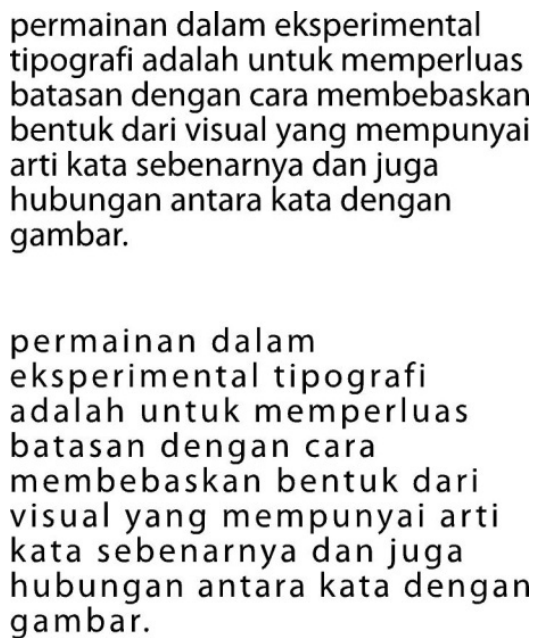




\section{Aturan 10}

Gunakan panjang kolom yang pantas, tidak terlau panjang dan juga tidak terlalu pendek untuk mempermudah prose's membacanya. Jika kolom terlalu panjang maka kita akan monoton dan tidak berirama dan membuat mata kita cepat lelah karena mengikuti garis yang panjang. Begitu pula jika terlalu pendek, membacanya terpotong potong, sehingga kita sulit membacanya.

Contoh:

$$
\begin{aligned}
& \text { permainan dalam eksperimental tipografi adalah untuk memperluas batasan } \\
& \text { dengan cara membebaskan bentuk dari visual yang mempunyai arti kata } \\
& \text { sebenarnya dan juga hubungan antara kata dengan gambar. }
\end{aligned}
$$

permainan dalam eksperimental
tipografi adalah untuk memperluas
batasan dengan cara
membebaskan bentuk dari visual
yang mempunyai arti kata
sebenarnya dan juga hubungan
antara kata dengan gambar.

\author{
permainan \\ dalam \\ eksperimental \\ tipografi \\ adalah untuk \\ memperluas \\ batasan \\ dengan cara \\ membebaska \\ $\mathrm{n}$ bentuk dari \\ visual yang \\ mempunyai \\ arti kata \\ sebenarnya
}

\section{Aturan 11}

Untuk keterbacaan yang baik gunakan jarak spasi yang tidak terlau jauh ataupun terlau dekat supaya memudahkan mata kita menangkap baris kalimat berikutnya. Spasi yang pendek (terlalu dekat) menyebabkan kita lambat membaca karna mengulang ulang mencari baris kalimat berikutnya, karena mata kita menangkap sekaligus beberapa baris berikutnya. Dengan menambah jarak spasi 1-4 poin maka mata kita akan lebih mudah menangkap baris berikutnya.

Contoh:

Spasi yang terlalu dekat; Untuk keterbacaan yang baik gunakan jarak spasi yang tidak terlalu jauh ataupun terlau dekat supaya memudahkan mata kita menangkap baris kalimat berikutnya. Untuk keterbacaan yang baik gunakan jarak spasi yang tidak terlau jauh ataupun terlau dekat supaya memudahkan mata kita menangkap baris kalimat berikutnya.

Spasi yang terlalu jauh: Untuk keterbacaan yang baik gunakan jarak spasi yang tidak terlau jauh ataupun terlau dekat supaya memudahkan mata kita menangkap baris kalimat berikutnya. Untuk keterbacaan yang baik gunakan jarak spasi yang tidak terlau jauh ataupun terlau dekat supaya memudahkan mata kita menangkap baris kalimat berikutnya.

\section{Aturan 12}

Untuk keterbacaan yang maksimum gunakan alignment RATA KIRI, atau disebut juga "flush left" | "left alignment”. Hal ini disebabkan karena penulisan latin dan kebiasaan kita menulis dari kiri ke kanan.Walaupun dari beberapa kemungkinan metode alignment tidak terlalu mengganggu layout, sesuai dengan kebutuhan dan tujuan informasi yang akan disampaikan. Juga dapat untuk teks yang tidak terlalu panjang sehingga tetap mudah keterbacaannya. 
Contoh:

Alignment RATA KIRI

Diharap kehadirannya pada acara alumnus Sekolah Desain pada acara Kumpul Kangen 2010, akan diadakan Pada tanggal 22 Mei 2010, pukul 10.00 - selesai

Bertempat di Gedung Pertemuan Jakarta jl. Kebayoran Lama No 54, Jakarta Selatan

Alignment RATA TENGAH

Diharap kehadirannya pada acara alumnus Sekolah Desain pada acara Kumpul Kangen 2010,

Akan diadakan Pada tanggal 22 Mei 2010, pukul 10.00 - selesai

Bertempat di Gedung Pertemuan Jakarta jl. Kebayoran Lama No 54, Jakarta Selatan

Alignment RATA KANAN

Diharap kehadirannya pada acara alumnus Sekolah Desain pada acara Kumpul Kangen 2010, akan diadakan Pada tanggal 22 Mei 2010, pukul 10.00 - selesai

Bertempat di Gedung Pertemuan Jakarta jl. Kebayoran Lama No 54, Jakarta Selatan

Alignment JUSTIFIED

Diharap kehadirannya pada acara alumnus Sekolah Desain pada acara Kumpul Kangen 2010, akan diadakanPada tanggal 22 Mei 2010, pukul 10.00 - selesai Bertempat di Gedung Pertemuan Jakarta jl. Kebayoran Lama No 54, Jakarta Selatan

\section{Aturan 13}

Tetap konsisten pada bentuk atau potongan akhir kalimat sehingga membentuk paragraph yang baik secara visual dan mempunyai irama yang berulang (tidak berbeda jauh dengan sebelumnya). Hindari bentuk rag yang tidak beraturan yang terbentuk dari pemotongan kata pada setiap baris kalimat. Juga hindari rags yang berulang yang membuat visual seakan pengulangan yang berkelanjutan atau disebut juga patern.

Contoh:

"Rag” yang tampak teratur

Tetap konsisten pada bentuk atau potongan akhir

kalimat sehingga membentuk paragraph yang baik

secara visual dan mempunyai irama yang berulang

(tidak berbeda jauh dengan sebelumnya)

"Rag” yang tidak teratur

Tetap konsisten pada bentuk atau potongan akhir kalimat

sehingga membentuk paragraph yang baik secara visual dan

mempunyai irama yang berulang (tidak berbeda jauh dengan sebelumnya)

\section{Aturan 14}

Jelas terlihat jika memang menunjukkan sebuah paragraph, jangan merancukan visual dengan bentuk yang terjadi pengulangan bentuk paragraph yang konsisten. Dua hal yang biasanya menidentifikasikan paragraph adalah masuknya huruf pertama pada awal paragraph dan menambah spasi diantara baris kalimat. Tidak selamanya hal ini tidak selalu mengidentifikasikan pergantian paragraph.

Contoh:

Awal paragraph yang menggunakan TAB KE DALAM

Jelas terlihat jika memang menunjukkan sebuah

paragraph, jangan merancukan visual dengan

bentuk yang terjadi pengulangan bentuk paragraph yang konsisten. 
Jelas terlihat jika memang menunjukkan sebuah paragraph, jangan merancukan visual dengan bentuk yang terjadi pengulangan bentuk paragraph yang konsisten.

Awal paragraph yang menggunakan JARAK

Jelas terlihat jika memang menunjukkan sebuah paragraph, jangan merancukan visual dengan bentuk yang terjadi pengulangan bentuk paragraph yang konsisten.

Jelas terlihat jika memang menunjukkan sebuah paragraph, jangan merancukan visual dengan bentuk yang terjadi pengulangan bentuk paragraph yang konsisten.

\section{Aturan 15}

Hindari widows dan orphans selagi memungkinkan. Widows (kata yang tertinggal di awal atau akhir paragraph) dan orphans (pemenggalan kata yang tertinggal di akhir paragraf) atau bisa terjadi pemenggalan kata di halaman sebelumnya atau terlempar ke halaman berikutnya). Dalam mendesain buku kedua hal ini dapat menciptakan kesatuan copy text, juga seperti noda dalam area kosong dan memecahkan konsentrasi membaca.

Contoh:

"Widows" (kata yang tertinggal di awal atau akhir paragraph) dan "orphans” (pemenggalan kata yang tertinggal di akhir paragraph ) atau bisa terjadi pemenggalan kata di halaman sebelumnya atau terlempar ke halaman berikut nya)

\section{Aturan 16}

Elemen empasis (penekanan) diusahakan tidak mengganggu alur membaca.Sebaiknya jangan berlebihan untuk memperlakukan penekanan dalam suatu kalimat, sehingga dapat memperjelas isi dan tidak merancukan pemikiran pembaca.

Contoh:

PENEKANAN MENGGUNAKAN JENIS HURUF YANG BOLDSebaiknya jangan berlebihan untuk memperlakukan penekanan dalam suatu kalimat, sehingga dapat memperjelas isi dan tidak merancukan pemikiran pembaca. PENEKANAN MENGGUNAKAN JENIS HURUF YANG ITALIC, UNDERLINE DAN PEMBESARAN UKURAN (TERLALU BERLEBIHAN

Sebaiknya jangan berlebihan untuk memperlakukan penekanan dalam suatu kalimat, sehingga dapat memperjelas isi dan tidak merancukanpemikiran pembaca.

\section{Aturan 17}

Selalu menjaga kesatuan bentuk satuan huruf , jangan merusak proporsi bentuknya. Desainer tipo telah menciptakan huruf dengan baik secara proporsional dan mempunyai karakter di setiap hurufnya yang membuat satuan huruf nya mudah terbaca dan jika digabungkan menjadi kata dan kalimat juga sangat mudah dibaca. 
Contoh:

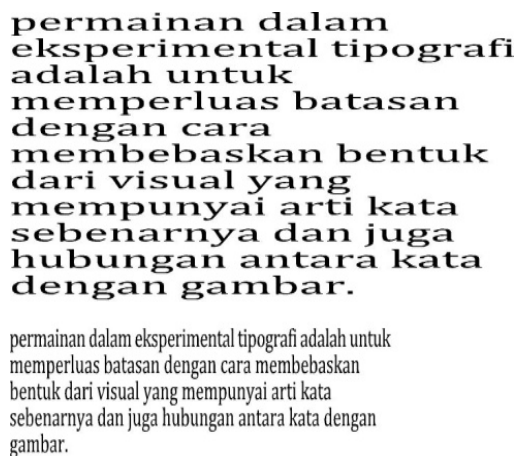

\section{Aturan 18}

Pada tiap hurufnya selalu di tulis/ divisualkan dengan menggunakan baseline (garis dasar atau basis) yang segaris. Huruf didesain untuk ditulis berdampingan sesuai di atas garis basis yang maya. Jika tidak sesuai penulisannya maka akan sulit terbaca karena berantakan (tidak teratur).

Contoh:

$$
\begin{aligned}
& \text { permainan dalam eksperimental } \\
& \text { tipografi adalah untuk memperluas } \\
& \text { batasan dengan cara } \\
& \text { membebaskan bentuk dari visual } \\
& \text { yang mempunyai arti kata } \\
& \text { sebenarnya dan juga hubungan } \\
& \text { antara kata dengan gambar. }
\end{aligned}
$$

\section{Aturan 19}

Jika huruf divisualkan mengunakan warna, perhatikan kontras warna, terang gelapnya warna, dan saturasi warna yang dipakai; karena sangat mempengaruhi keterbacaan huruf-hurufnya. Jika warna yang tidak terlalu kontras antara huruf dan warna latar belakangnya akan membuat kita sukar untuk membaca.

Contoh:

putih di atas hitam
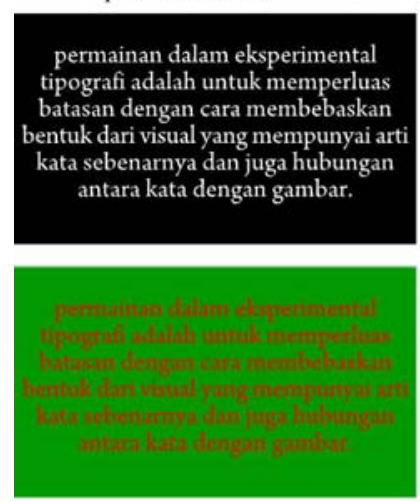

merah di atas hijau putih di atas kuning

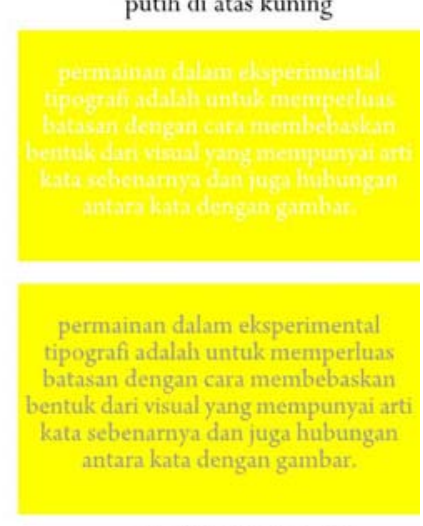

abu-abu diatas kuning

\section{Melanggar Aturan Main dalam Tipografi}

Tipografi mempunyai tugas utama sebagai penyampai pesan selain itu juga sebagai inspirasi permainan visual yang menarik walaupun dihasilkan dari sesuatu yang diluar dari sesuatu yang teratur. 
Dari permainan eksperimental tipo bisa kita dapatkan suatu keindahan yang unik dalam memecahkan masalah komunikasi visualnya dengan mendobrak gaya-gaya visual lama yang berkesan teratur rapi.

Untuk mendapatkan efektifitas dan kebebasan untuk bereksplorasi dalam tipografi sebaiknya kita harus dapat memilih melawan konsep dasar dan keinginan yang standar.Untuk para pemula hal ini bukan yang sulit, tapi untuk desainer terkemukahal ini menjadi sebuah tantangan besar yang sangat kuat.Membuat karya visual yang masih baru, membantu mengubah rumusan atau aturan dan menjadikan suatu karya yang memberikan tatangan yang terarah. Karena tipo diciptakan untuk dibaca membangun sebuah pemikiran yang sintaktis, sadar tidak sadar dimanapun dan berbentuk apapun kita akan berusaha membaca karya typo. Sehingga langkah pertama pembuatan karya tipo ini harus di sadarkan bahwa tidak selamanya karya tipo untuk dibaca.Sehingga memungkinkan untuk berkarya tipografi secara eksperimental. Morfologi merupakan salah satu factor yang memudahkan pelaksanaan tipografi eksperimental, karena morfologidalam studi desain grafis mempelajari tentang bentuk dalam kata (linguistik).

Bagian bab ini memberitahukan kepada kita bahwa morfologi dapat memberikan petunjuk untuk menciptakan visual ekperimental tipografi dengan beberapa penggabungan antara tipografi, bentuk, bidang dan elemen elemen tipo lainnya yang mendukung. Tipografi itu sendiri untuk memanipulasi bentuk huruf dan kata kata (tipo sebagai bagian dari image). Bentuk itu sendiri sebagai bagian dari pengembangan bentuk dasar huruf itu sendiri. Bidang, dimana ruang/bidang tersebut dapat menghubungkan satu dengan yang lain elemen2 yang terdapat didalam satu bidang. Elemen-elemen pendukung tipo yang menjadikan lebih fungsi tipo itu sendiri. Penyesuaian bentuk huruf dengan gambar, sehingga menciptakan huruf baru setelah eksplorasi bentuk.

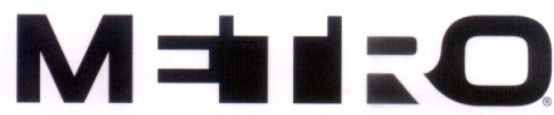

Gambar 1 Sebagai contoh distorsi huruf yang merupakan perubahan dari form/ bentuk

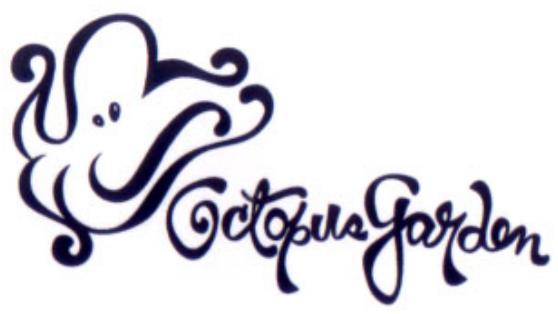

Gambar 2 Sebagai contoh distorsi huruf yang merupakan perubahan dari form/ bentuk

\section{Eksperimen dalam Tipografi}

Dalam pembahasan eksperimen dalam tipografi disini akan menitik beratkan pada bentuk form yang dihasilkan dari huruf itu sendiri yang akan di interpretasi dan di telaah oleh pembuatnya sehingga dapat menciptakan tujuan komunikasi apa yang akan disampaikan. Ada juga yang hanya merupakan karya seni. Akan ada beberapa contoh karya mahasiswa di bawah ini. Dalam penciptaan ini biasanya mahasiswa tetap harus menggunakan sketsa untuk menuangkan ide ide dasar, yang nantinya akan di ciptakan atau divisualkan secara digital, di sini mahasiswa dapat merasakan tahapan awal sketsa yang merupakan awal dari bentukan layout kasar hitam putih menjadi sebuah karya digital detail, sehingga dapat merasakan perjalanan eksplorasinya. 


\section{Eksperimen dalam Tipografi}

Dapat dilakukan melalui beberapa eksperimen dengan cara melanggar prinsip-prinsip dasar atau aturan aturan main yang telah diuraikan di atas.

\section{Eksperimen 1 \\ Huruf Besar \& Huruf Kecil}

Hampir semua huruf di desain huruf besar dan huruf kecil sesuai dengan kegunaannya, tetapi pada eksperimen 1 penggunaan huruf besar semua atau huruf kecil semua bukan menjadi suatu kesalahan, bahkan percampuran keduanya yang dipakai bersamaan menjadikan variasi dalam visual anda.

Contoh

Menggunakan huruf kecil semua

hampir semua huruf di desain huruf besar dan huruf kecil sesuai dengan kegunaannya, tetapi pada eksperimen 1 penggunaan huruf besar semua atau huruf kecil semua bukan menjadi suatu kesalahan, bahkan percampuran keduanya yang dipakai bersamaan menjadikan variasi dalam visual anda.

Menggunakan huruf besar semua HAMPIR SEMUA HURUF DI DESAIN HURUF BESAR DAN HURUF KECIL SESUAI DENGAN KEGUNAANNYA, TETAPI PADA EKSPERIMEN 1 PENGGUNAAN HURUF BESAR SEMUA ATAU HURUF KECIL SEMUA BUKAN MENJADI SUATU KESALAHAN, BAHKAN PERCAMPURAN KEDUANYA YANG DIPAKAI BERSAMAAN MENJADIKAN VARIASI DALAM VISUAL ANDA.

Menggunakan variasi huruf besar \& kecil semua HAMPIR SEMUA HURUF DI DESAIN HURUF BESAR DAN HURUF KECIL sesuai dengan kegunaannya, tetapi pada eksperimen 1 penggunaan HURUF BESAR SEMUA ATAU HURUF KECIL SEMUA BUKAN MENJADI suatu kesalahan, bahkan percampuran keduanya yang dipakai BERSAMAAN MENJADIKAN VARIASI DALAM VISUAL ANDA

\section{Eksperimen 2}

\section{Pemilihan Jenis Huruf}

Dalam eksperimen tipografi yang terpenting adalah pemilihan huruf, diantara sekian juta pilihan jenis huruf yang disesuaikan dengan kebutuhan dan karakter desain yang akan disampaikan.

Contoh:

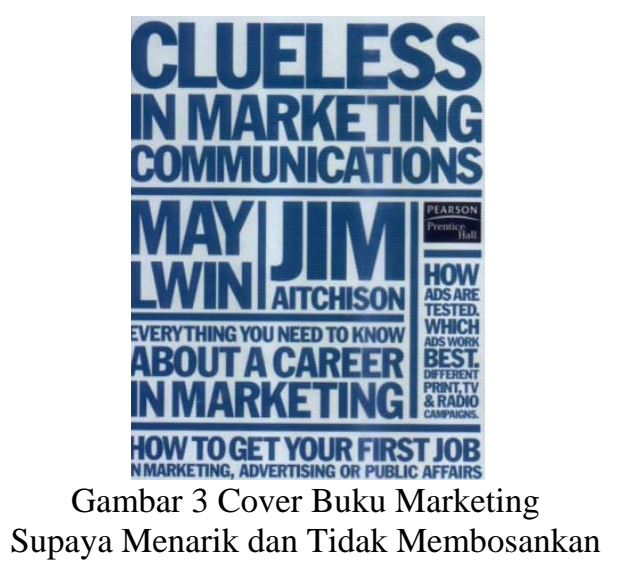




\section{Eksperimen 3}

\section{Permainan Besar Kecilnya \& Tebal Tipisnya Ukuran Huruf}

Dengan melakukan pembesaran/pengecilan dan tebal/kecilnya ukuran huruf akan menciptakan kedalaman ruang pada layout, sehingga dapat memberikan penekanan karakter pada tiap kata atau hurufnya itu sendiri.

\section{Eksperimen 4}

\section{Slanted (Kemiringan)}

Dengan melakukan kemiringan pada visual huruf (biasa kita sebut italic) maka karakter huruf tersebut terlihat seperti bergerak untuk maju atau dinamis. Kemiringan biasanya hanya 13-16 derajat, karena jika terlalu berlebih maka faktor keterbacaan akan lebih sulit.

\section{Eksperimen 5 \\ Blending (Metode Campuran/Gradasi Pewarnaan/ Tekstur Pada Huruf)}

Membuat prubahan warna dengan gradasi antar warna atau hanya terang gelap yang dapat membuta ilusi terang gelapnya huruf tersebut sehingga menciptakan ilisi dimensi. Ilusi bisa membentuk kedalaman, pergerakan atau kontras warna. Jika penggunaan tekstur pada huruf akan memberikan sensasi atau kesan kusus. Semua memberikan kesan yang individual, tergantung pada visual tekstur bisa dirasakan tepat atau tidak mengganggu atau sebaliknya (halus/kasar). Pada penggunaan tekstur ukuran besarnya huruf sangat mempengaruhi perubahan bentuk, juga bentuk dari tekstur itu sendiri. Misalnya garis, dot, atau bentuk geomatris yang berulang.

\section{Eksperimen 6 \\ Distorsi Huruf}

Membuat distorsi pada huruf merupakan perjalanan penguasaan bentuk untuk menjadi simbol ekspresif. Jika font berubah bentuk maka akan menimbulkan kesan aneh dan tidak biasa. Tergantung dari bentuk distorsinya, karena menyangkut pengembangan arti bentuk huruf tersebut. Misalkan bentuk kata yang di distorsi secara skew akan memvisualkan sebuah kata yang bergerak. Atau contoh lain dibuat perspektif, maka akan menciptakan visual ruang. Dan masih banyak lagi contoh-contoh hasil dari distorsi huruf.

\section{Eksperimen 7}

\section{Groupping (Pengelompokkan Huruf)}

Merupakan prinsip desain yang utama, yang menjadikan harmonis dan bersatu diantara element huruf yang dapat menghindari keanehan dan ketidak samaan bentuk pada elemennya.

\section{Eksperimen 8 \\ Repetisi Huruf}

Membuat repetisi pada huruf dapat mengganggu tapi cukup mempunyai fungsi yang maksimal untuk mengkomunikasikan pesan. Repetisi merupakan salah satu faktor penting dalam pengembangan tipografi, penekanan yang lebih tinggi dan dibesar-besarkan, walaupun bentuk yang kadang tidak enak atau mengganggu. Repetisi atau pengulangan dapat berupa huruf, kata atau kalimat sehingga bisa juga menciptakan visual untuk pattern.

\section{Eksperimen 9 \\ Rotasi Huruf}

Membuat huruf atau kata yang diputar dengan putaran derajat adalah bentuk yang dasar sekali dan mudah pengaplikasiannya, tetapi hasil yang diciptakan sangat besar memberikan energi dan emosi dari arti/visual kata tersebut sehingga lebih dinamis dibandingkan dengan yang rata. 


\section{Eksperimen 10 \\ Ruled Line}

Dengan menambahkan garis maka akan menambah efek visual pada huruf atau kata tersebut. Bisa sebagai penekanan kata atau variasi pembentukan bidang juga dapat membawa kita ke suasana yang berbeda.

\section{Eksperimen 11}

\section{Menambah Shape atau Simbol}

Dengan menambahkan shape (bidang yang berbentuk) pada komposisi tipo akan menciptakan satu kesatuan bentuk dengan tipo itu sendiri, bisa sebagai penekanan atau bahkan pemisah. Visualisainya dapat juga dibuat overlap dengan tipografinya. Penggunaan simbol yang dapat berupa dingbats atau tanda baca, isotipe dan lain-lain, bisa disatukan dengan kata atau berdiri sendiri sehingga dapat menjadi kesatuan atau menimbulkan makna arti yang berbeda.

Contoh:

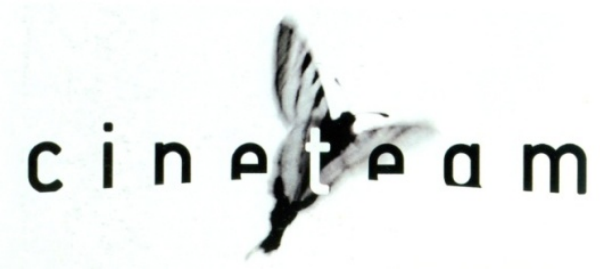

Gambar 4 Logo CineTeam dengan penambahan gambar

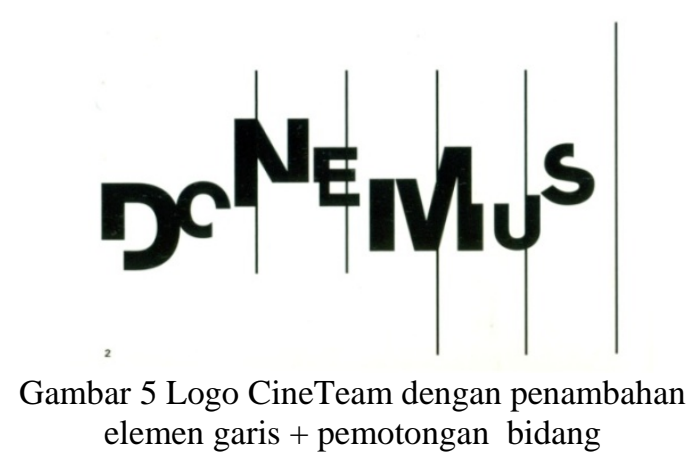

\section{Eksperimen 10}

Image (Gambar)

Membuat huruf/kata yang diputar dengan putaran derajat adalah bentuk yang dasar sekali dan mudah pengaplikasiannya, tetapi hasil yang diciptakan sangat besar memberikan energi dan emosi dari arti/visual kata tersebut sehingga lebih dinamis dibandingkan dengan yang rata.

\section{Pelaksanaan Ekperimental Dalam Visual}

Dalam pembahasan eksperimen dalam tipografi disini dihasilkan dengan cara mengetahui kaidah kaidah dasar dari ilmu tipografi, dan aturan aturan yang dilanggar tetapi tidak keluar dari konteks dan konten sebagai desain komunikasi visual. Walaupun karya seni pun dapat dihasilkan dengan menjalankan hal serupa akan tetapi disini pengembangan dilakukan untuk menujang ide kreatif yang dapat dihasilkan dari permainan layout tipografi itu sendiri. Sehingga dapat menghasilahan desain desain yang unik dan menarik, tidak sekedar desain yang teratur dan biasa. Pada bentuk visualnya dihasilkan dari huruf yang akan diinterpretasi dan ditelaah oleh pembuatnya sehingga dapat menciptakan tujuan komunikasi apa yang akan disampaikan. 


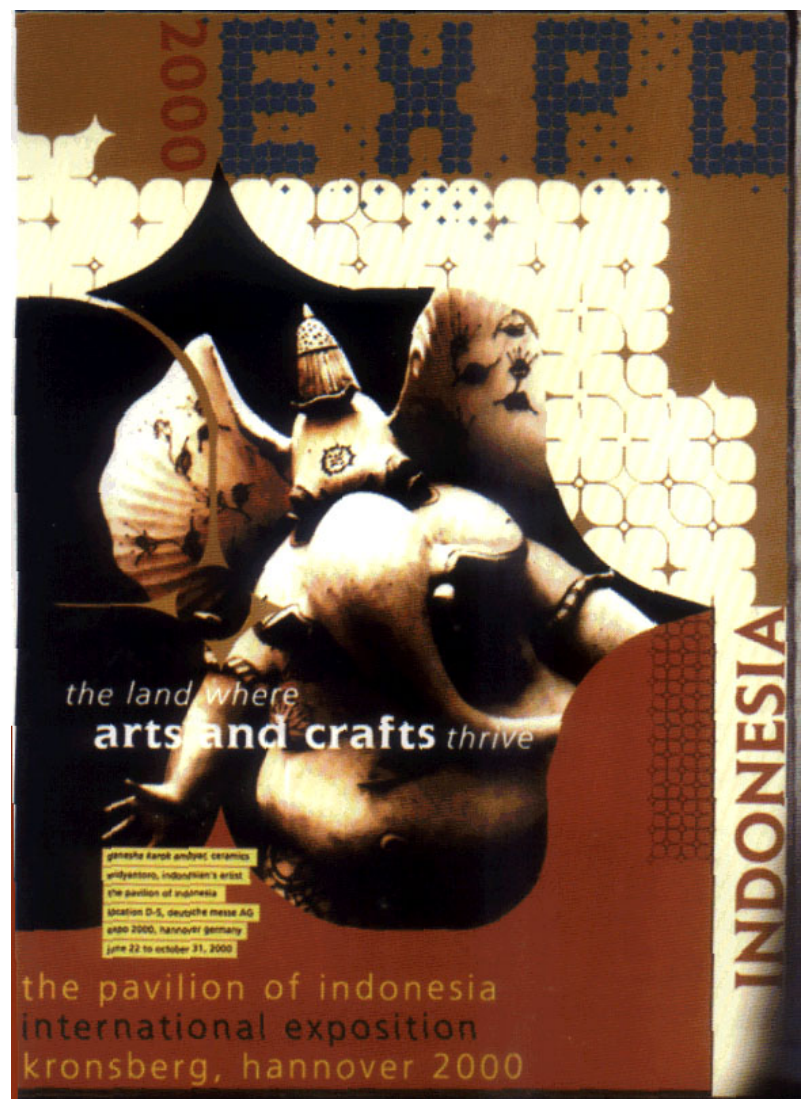

Gambar 6 Berupa Poster EXPO tahun 2000

\section{PENUTUP}

Dengan mengetahui kaidah kaidah dasar pengetahuan tentang tipografi, kita dapat mempelajari aturan aturan dasarnya, kita dapat melanggar aturan tersebut untuk digunakan dalam membuat eksperimen dalam melayout tipografi, sehingga visual akan lebih menarik dan unik, sesuai dengan konteks nya sebagai desain komunikasi visual yang mempunyai target audience tertentu.

\section{DAFTAR PUSTAKA}

Carter, R. (1997). Working with Computer Type 4, Experimental Typography. Swiss: Rotovision.

Carter, R., Day, B., \& Meggs, P. (2007). Typographic Design: Form and Communication (4th ed.). New Jersey: John Wiley \& Sons.

Sihombing, D. (2003) Tipografi dalam Desain Grafis. Jakarta: Gramedia Pustaka Utama. 